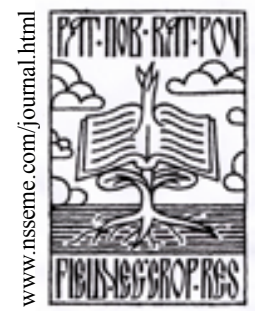

\title{
The Prediction of Heterosis Based on the Phenotypic Distance of Sweet Maize Parental Lines
}

\author{
Vojka Babić • Jelena Srdić • Zorica Pajić • Nikola Grčić • Milomir Filipović
}

\author{
received: 14 April 2014, accepted: 14 May 2014 \\ published online: 10 June 2014 \\ (C) 2014 IFVC \\ doi:10.5937/ratpov51-5915
}

\begin{abstract}
Summary: A relatively narrow genetic background, limited sources of germplasm that satisfies commercial standards, poorly defined heterotic groups, as well as a small span for yield and quality estimation are reasons for the modest improvement in sweet corn yields in comparison with standard grain quality maize. Therefore, any additional information could be of a great use. Based on the phenotypic characterization according to UPOV descriptor, phenotypic distances of 14 ZP sweet corn inbred lines were evaluated, and clustering was performed. Grouping showed that 9 out of 11 hybrids obtained by crossings of 14 sweet corn inbred lines had parental lines assigned to different subclusters. Two hybrids whose parental components belonged to the same subcluster had some important specific traits, such as early maturity (ZP 111su), and super-sweet germplasm (ZP 407su). Results obtained by this procedure could be of great assistance in the process of selecting parental lines for the future crossings.

Key words: germplasm, heterosis, hybrids, inbred lines, phenotypes, sweet corn, UPOV descriptor, Zea mays L. saccharata
\end{abstract}

\section{Introduction}

The efficiency of maize breeding programs would be significantly enhanced if superior crosses could be predicted before field evaluation based on screening of parental inbred lines. Even though remarkable advances in maize breeding have been achieved, field trials involve significant resources and are time consuming. However, field tests still have an irreplaceable role in modern hybrid breeding programs. Determining performances of inbred lines as potential hybrid parents in field experiments and diallel crosses are still widely used in sweet corn breeding programs (Kashiani et al. 2010, Assuncao et al. 2010). The discovery of heterotic groups reduced the number of test crosses in field maize. Any new inbred line with good combining abilities can be included into breeding program of field maize, where the yield is emphasized. In sweet corn breeding, greater number of selection criteria are applied, and at the same time, sources of germplasm satisfying

V. Babić* $\cdot$ J. Srdić $\cdot$ Z. Pajić · N. Grčić · M. Filipović

Maize Research Institute "Zemun Polje", 1 Slobodana Bajića, 11185 Belgrade, Serbia

e-mail:vbabic@mrizp.rs commercial standards are scarce. The genetic background of sweet corn is relatively narrow; hence related inbreds are crossed in order to obtain hybrids that will achieve high criteria related to ear quality and appearance dictated by the market (Tracy 2001). Not only that the narrow genetic background is available, but also heterotic groups are poorly defined (Tracy et al. 2000, Revilla et al. 2005, Bered et al. 2005). On the other hand, there are only few reports on significant genetic diversity in sweet corn germplasm that could suggest the formation of heterotic groups (Revilla et al. 2006, Rupp et al. 2009). The greatest number of sweet corn inbreds was derived from the following three open-pollinated varieties: Golden Bantam, Stowell's Evergreen and Country Gentleman (Tracy 2001). Heterotic and phylogenetic relations among these three varieties are not clearly defined. Therefore, advancement in breeding for sweet corn yield in relation to field maize is modest. Tracy (1990) studied the possibility to improve sweet

\section{Acknowledgements:}

Part of this work was supported by the Ministry of Education, Science and Technological Development of the Republic of Serbia through the Project "Maize and Soybean Traits Improving by Molecular and Conventional Breeding" (TR 31068). 
corn breeding by the development of heterotic groups and came to the conclusion that the most real starting point should be the division of the existing sweet corn germplasm based on phylogenesis (evolutionary origin). The efficiency of breeding programs would be significantly improved if sweet corn hybrid performances could be somehow estimated prior to field evaluations. Beside standard procedures in the course of sweet corn breeding, a special attention has to be paid to technological product properties, intended use and markets.

Morphological traits are traditionally used in the description and this trend will surely continue. Nevertheless, many authors consider these traits unreliable as they have been created by abundant measures of a great number of plants; they are under great influence of the environment and under an unknown mechanism of genetic control (Smith \& Smith 1989).

The UPOV descriptor presents the procedure and the conduct of tests for distinctness, uniformity and stability (DUS) of the new varieties of plants for the purpose of granting breeder's rights at the international level. Furthermore, there is a need to monitor a certain number of traits of phenotypes according to the UPOV descriptor within commercial breeding programs, carried out by countries members of UPOV and the European Union. Such information is necessary in the process of releasing new varieties and for their listing into National or Common European Catalogue of
Varieties of Agricultural Plant Species. Some studies found that in field maize, phenotypic characterization by visual assessment of a group of plants according to UPOV descriptor could be used for grouping inbred lines according to their similarity (Babić et al. 2008, Babić et al. 2011). A similar procedure was applied on sweet corn inbred lines and obtained results were in high accordance with known pedigree of inbreds involved in the study (Babić et al. 2010).

The aim of this study was to determine if the phenotypic characterization according to UPOV descriptor could be used in the course of improvement of testing sweet corn inbred lines, and if the phenotypic distances obtained by visual assessment of the group of plants (VG) could be a reliable indicator in planning future crossings in sweet corn breeding program.

\section{Materials and Methods}

This study included 14 elite sweet corn inbred lines of the known pedigree selected in Maize Research Institute "Zemun Polje", which are parental components of $11 \mathrm{ZP}$ sweet corn hybrids (Tab. 1 and Tab. 2).

Selected sweet corn inbred lines and hybrids were sown in two rows with 20 plants and in two replications in one year. The first row was used for phenotypic description, and the second for the yield evaluation. Phenotypic description was performed according to UPOV descriptor (UPOV 1999, UPOV 2009), visually assessed

Table 1. Pedigree data of the observed sweet corn inbred lines

\begin{tabular}{|c|c|}
\hline Inbred line & Pedigree data \\
\hline ZPLsu 1 & Derived from the $\mathrm{F}_{2}$ population of the sweet corn. \\
\hline ZPLsu 2 & From the crossings of sweet corn and dent line $\mathrm{K} 8$ from the Iranian population. \\
\hline ZPLsu 3 & $\begin{array}{l}\text { From the crossing of (Talqueno } \mathrm{x} \text { R } 588 \text { ) x sweet corn, where Talqueno is Mexican dent variety and } \mathrm{R} \\
588 \text { is line obtained from domestic dent population "Rumski zuban". }\end{array}$ \\
\hline ZPLsu 4 & $\begin{array}{l}\text { From the crossing of (Talqueno } \mathrm{x} \text { (588) x sweet corn, where Talqueno is Mexican dent variety and R } \\
588 \text { is line obtained from domestic dent population "Rumski zuban". }\end{array}$ \\
\hline ZPLsu 5 & From the sweet corn population Golden Bantam. \\
\hline ZPLsu 6 & Derived from the $\mathrm{F}_{2}$ sweet corn population. \\
\hline ZPLsu 7 & From the sweet corn population Golden Bantam. \\
\hline ZPLsu 8 & Derived from sweet corn population introduced from Mexico. \\
\hline ZPLsu 9 & From the crossings of sweet corn and dent line $\mathrm{K} 8$ from the Iranian population. \\
\hline ZPLsu 10 & Derived from the $\mathrm{F}_{2}$ sweet corn population. \\
\hline ZPLsu 11 & Derived from the $\mathrm{F}_{2}$ sweet corn population. \\
\hline ZPLsu 12 & Derived from the $\mathrm{F}_{2}$ sweet corn population. \\
\hline ZPLsu 13 & From the crossings of sweet corn and dent line $\mathrm{K} 8$ from the Iranian population. \\
\hline ZPLsu 14 & Derived from the $\mathrm{F}_{2}$ sweet corn population. \\
\hline
\end{tabular}


Table 2. ZP sweet corn hybrids and their parental lines

\begin{tabular}{lll}
\hline Hybrid & \multicolumn{1}{c}{ + } & ๙ \\
\hline ZP 355su & ZPLsu 3 & ZPLsu 2 \\
ZP 391su & ZPLsu 12 & ZPLsu 8 \\
ZP 407su & ZPLsu 6 & ZPLsu 5 \\
ZP 421su & ZPLsu 1 & ZPLsu 8 \\
ZP 424su & ZPLsu 14 & ZPLsu 8 \\
ZP 431su & ZPLsu 9 & ZPLsu 4 \\
ZP 441su & ZPLsu 10 & ZPLsu 8 \\
ZP 531su & ZPLsu 13 & ZPLsu 3 \\
ZP 555su & ZPLsu 11 & ZPLsu 3 \\
ZP 111su & ZPLsu 7 & ZPLsu 5 \\
ZP 401su & ZPLsu 4 & ZPLsu 5 \\
\hline
\end{tabular}

by a single observation of a group of plants or parts of plants (VG). Visual assessment of group of plants was chosen because it was performed on homozygote inbred lines that express high uniformity. Due to the high influence of the environment on the expression of quantitative traits, it was assumed that the application of scale measurement would introduce much confusion in defining morphological distances, rather than if we have used the rank of the expression of that trait compared to the control genotypes according to UPOV descriptor. It was presumed that effect of environment on the expression of traits would be lowered by degradation of measuring scale on the ordinal level and thereby reliability of morphological markers would be increased.

Out of 56 traits that were evaluated, the following 36 traits were used for the cluster analysis: intensity of anthocyanin coloration of the first leaf sheath, tip shape of the first leaf, position of the top leaf, angle between blade and steam and attitude of blade, degree of zig-zag of stem, intensity of anthocyanin coloration of brace roots, anthocyanin intensity in the base of tassel glumes, anthocyanin intensity of tassel glumes without the base, anthocyanin intensity of fresh anthers, tassel glumes density, angle, attitude and number of lateral tassel branches, anthocyanin intensity of silk, anthocyanin intensity of leaf sheath in the middle part of the plant, length of the main tassel branch above the highest and the lowest lateral tassel branch, plant height, total plant height to ear height ratio, ear leaf width, number of tillers, length of peduncle, husk cover, ratio net/gross of ear weight, ear length and diameter, ear form and curvature, kernel row number and row straightness, filled ear tips, diameter of cob, kernel colour, kernel brightness and depth, kernel size, thickness of pericarp, sugar content. A certain number of observed traits were rejected due to the fact that studied inbreds had uniform evaluations hence they would not be able to contribute to the discrimination.

Beside phenotypic characterization on the second row ear yield per plant with and without husk, shelling percentage was also measured. These estimates were used for determining heterosis for these traits, according to the mid parent and better parent estimate.

According to the phenotypic characterization, cluster analysis was performed (Complete Linkage method of grouping), where Euclidian square distance was used as the distance measure. Results are presented in the form of dendrogram. Obtained estimates of the Euclidian distances served for the calculation of phenotypic similarities showed on the correspondence analysis graph.

\section{Results and Discussion}

Observed sweet corn inbred lines formed three subclusters at dendrogram of their morphological similarity $(a, b, c)$ (Fig. 1). Subcluster $a$ encompassed 6 inbreds. The highest level of similarity was found between ZPLsu 10 and ZPLsu 14 that were derived from the same $F_{2}$ population, while the third inbred from this population, ZPLsu 11 was less related to them than ZPLsu 1 that originated from the $\mathrm{F}_{2}$ population of the other sweet corn hybrid. Also, in this subcluster were ZPLsu 4, obtained from the crossing of (Talqueno $x \mathrm{R} 588$ ) $\mathrm{x}$ sweet corn hybrid, and ZPLsu 13 derived from the crossings of sweet corn and inbred line K8 - dent line from the Iranian variety. 




Figure 1. Dendrogram of the cluster analysis of phenotypic distances of sweet corn inbreds

Subcluster $b$ consisted of two inbreds originating from the same $\mathrm{F}_{2}$ population (ZPLsu 2 and ZPLsu 9), and inbred ZPLsu 12 was obtained from the $F_{2}$ population of other sweet corn hybrid. The third subcluster $c$, included two inbreds selected from the sweet corn variety Golden Bantam (ZPLsu 7 and ZPLsu 5), ZPLsu 3 (from the crossing of Mexican dent $\mathrm{x}$ domestic dent population $\mathrm{x}$ sweet corn variety), ZPLsu 8 (from the sweet corn population introduced from Mexico), and ZPLsu 6 (from $F_{2}$ population of the sweet corn hybrid).

The overall picture shows that subclusters $a$ and $b$ are joined in a larger subcluster pointing to the higher morphological similarity between involved inbreds. Grouping of the observed inbred lines was mostly in agreement with their pedigree, bearing in mind narrow genetic base of sweet corn.

Oneofthepresumptionswasthatifthephenotypic distances truly reflect genetic relationship between inbreds, parental components of 11 sweet corn hybrids would be grouped in different subclusters (Tab. 2). Babić et al. (2011) reported such a case by studying the material of field maize, where 18 hybrids out of 20 involved in the study had parental components grouped in different clusters. In this study, parental components of nine, out of 11 observed sweet corn hybrids, were grouped into different subclusters (Fig. 1.). One of the hybrids whose parental components originated from the same subcluster is ZP 111su, which belongs to the FAO group 100, i.e. is an early maturity hybrid that reaches maturity in 65 days. That trait outreaches the demand for high yields in case of this hybrid. The second hybrid ZP 407su as the female component has super-sweet germplasm. Moreover, male component of both hybrids is inbred line derived from sweet corn variety Golden Bantam, which is the base of most of present sweet corn breeder gene pools. Although the starting point in reaching heterosis is in choosing genetically distinct material, it is not always possible to achieve when it comes to sweet corn. Since grain yield is not the only important sweet corn characteristic, crossing of less divergent material in sweet corn is justified by reaching other criteria such as early maturity, better resistance, or some traits important for fresh and processing market (Tracy 2001).

In order to obtain more detailed presentation of interrelationships of sweet corn inbred lines in this study, the distance matrix was used for correspondence analysis. Results presented on the graph are in accordance with cluster analysis, and moreover much more complete perspective of sweet corn inbreds interrelationships are revealed (Fig. 2.). The first dimension (D1) separates inbreds of subcluster $c$ from the others, while the second dimension (D2) distinguishes subclusters $a$ and $b$. The advantage of such presentation is that results 


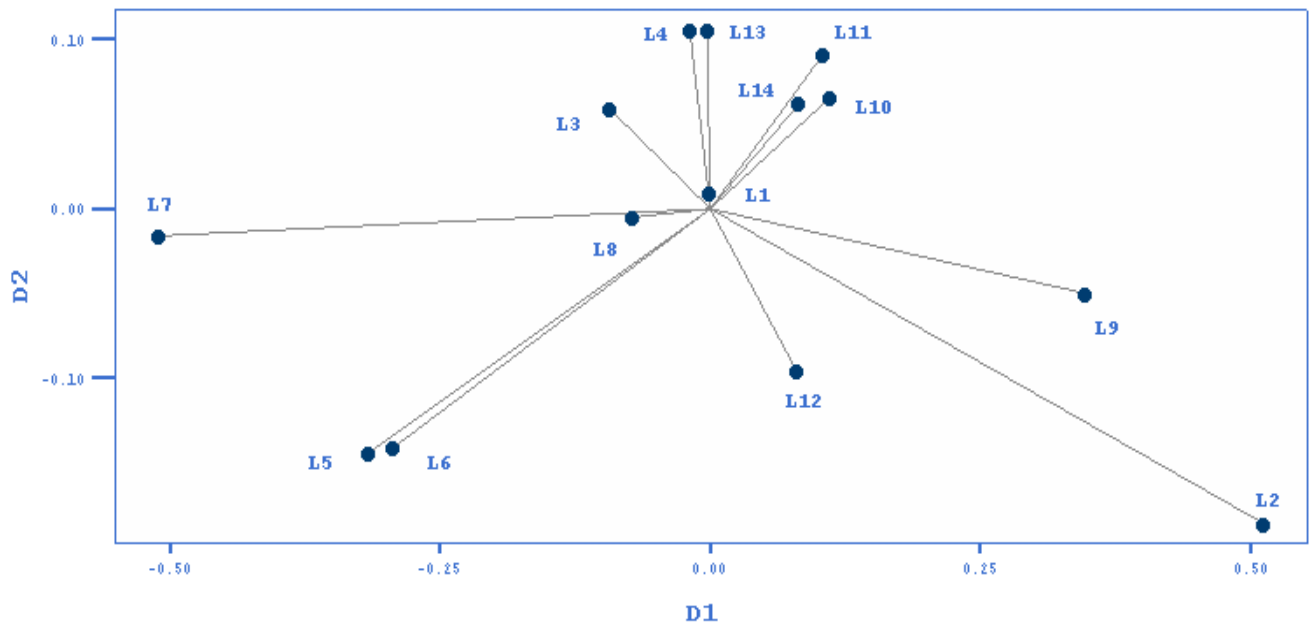

Figure 2. Figure of the correspondence analysis of phenotypic similarities of sweet corn inbreds

are presented in the form of continuous variation, while the cluster analysis presents results in the form of groups - clusters even when the continuality is present. It is noticed that inbreds ZPLsu 5 and ZPLsu 6 are morphologically very similar, although their pedigree is not. Such a case is also noticed between ZPLsu 4 and ZPLsu 13. This phenomenon can be explained in two ways in the theory of quantitative genetics. 1) First of all, it is known that different combinations of genes can result in the same phenotype. 2) On the other hand, it is also known that due to the inter-locus interaction a very different phenotype, even in a case of closely related parents, can occur (Babić et al. 2012). On the other hand, inbreds ZPLsu 10, 11 and 14 that originate from the same genetic source are very closely grouped on the figure of the correspondence analysis. Inbred lines ZPLsu 8 and 3 that are located in the subcluster $c$ are much more similar to the inbreds of the subcluster $a$. Inbreds belonging to subcluster $c$ had a negative value of D1axis, while on the other hand, inbreds from the subcluster $b$ were completely opposite to them and had positive value of the first dimension axis on the correspondence analysis graph. That indicates that inbreds from those two subclusters are morphologically very distinct. Those inbreds that occupied marginal positions on the graph, i.e. had the longest vectors (ZPLsu 5, 6, 7, 9, 2), are inbreds with the highest average estimates of phenotypic distances and are morphologically the most distant from the other observed lines. Thereafter it can be presumed that those inbreds could be good test lines.

Estimates of ear yield heterosis (with and without husk) were correlated to phenotypic distances. Although estimates of correlations between heterosis and phenotypic distances were positive (the larger the phenotypic distance between inbreds, the higher the heterosis), they were not significant $(r=0.39$ with husk; $r=0.42$ without husk). Moreover, those estimates were too low to be of any use in prediction of heterosis based on phenotypic distances. On the other hand, even different methods of molecular markers expressed relatively low correlations to heterosis. Furthermore, even when correlations were significant, they could not be used as predictive value of hybrid performances (Mladenović Drinić et al. 2002), but only for assessing inbred lines to distinctive heterotic groups (Reif et al. 2003, Pinto et al. 2003, Fan et al. 2003). Such case was also concerning sweet corn were relatively low to medium correlation was found between genetic similarity and heterosis or specific combining ability (Srdić et al. 2011). Nevertheless, concerning narrow genetic base and the lack of information about heterotic patterns in sweet corn, these data could be very valuable in sweet corn breeding programs.

\section{Conclusions}

In our study we found that phenotypic characterization and clustering of inbreds according to that was a very good indication how inbreds should be combined in order to produce perspective sweet corn hybrids. The results of the clustering of 14 sweet corn inbreds were in accordance with the performances of eleven ZP sweet corn hybrids that stand out by their yields or other significant technological properties. Namely, nine out of eleven hybrids were formed by inbreds assigned in different subclusters. The two hybrids whose inbreds were in the same subclusters had some 
other specific traits that overcame the demand for the higher yield. It should be emphasized that the phenotypic characterization by visual assessment of a group of plants or parts of plants, according to UPOV descriptor, is simple, does not require great investments and is not labour consuming. At the same time, that provides sufficient information that can be used in the process of selection and breeding, especially when modern multivariate statistic methods are applied. Sweet corn field trials are more complex and more expensive than trials of standard grain quality hybrids and therefore any supporting tool for a rapid development of new hybrids is essential.

\section{References}

Assuncao, A., Madureira Brasil, E., Pereira de Oliveira, J., dos Santos Reis, A.J., Ferreira Pereira, A., Bueno, L.G., \& Ribeiro Ramos, M. (2010). Heterosis performance in industrial and yield components of sweet corn. Crop Breed Appl Biotechnol 10, 183-190.

Babić, M., Babić, V., Prodanović, S., Filipović, M. \& Andjelković, V. (2012). Comparison of morphological and molecular genetic distances of maize inbreds. Genetika, 44 (1), 119-128.

Babić, V., Pajić, Z., Prodanović, S., Babić, M., \& Filipović, M. (2010). Visual assessment of sweet maize lines phenotype, according to UPOV descriptor, as indicator of heterosis. Genetika, 42 (2), 313-322.

Babić, V., Babić, M., Filipović, M., Delić, N., \& Andjelković, V. (2008). Phenotypic characterization and relatedness of maize inbred lines. Genetika, 40 (3), 227-236.

Babić, V., Babić, M., Filipović, M., Delić, N., \& Purar, B. (2011). Vizuelna ocena fenotipa po UPOV deskriptoru i srodnost linija kukuruza. Ratarstvo i povrtarstvo, 48 (2), 321-326.

Bered, F., Terra, T.F., Spellmeier, M., \& Barbosa, N.J.F. (2005). Genetic variation among and within sweet corn populations detected by RAPD and SSR markers. Crop Breed Appl Biotechnol, 5, 418-425.

Fan, X.M., Tan, J., Chen, H.M., \& Yang, J.Y. (2003). Heterotic grouping for tropical and temperate maize inbreds by analyzing combining ability and SSR markers. Maydica, 48, 251-257.
Kashiani, P., Saleh, G., Abdullah, N.A.P., \& Abdulah, S.N. (2010). Variation and genetic studies on selected sweet corn inbred lines. Asian J Crop Sci., 2(2), 78-84.

Mladenović Drinić, S., Trifunović, S., Drinić, G., \& Konstantinov, K. (2002). Genetic diversity and its correlation to heterosis in maize as revealed by SSR based markers. Maydica, 47, 1-8.

Pinto, R. de M.C., Souza, Jr. de C.L., Carlini-Garcia, L.A., Garcia, A.A.F., \& Pereira de Souza, A. (2003). Comparison between molecular markers and diallel crosses in the assignment of maize lines to heterotic groups. Maydica, 48, 63-73.

Reif, J.C., Melchinger, A.E., Xia, X.C., Warburton, M.L., Hoisington, D.A., Vasal, S.K., Srinivasan, G., Bohn, M., \& Frisch, M. (2003). Genetic distance based on simple sequence repeats and heterosis in tropical maize populations. Crop Sci., 43, 1275-1282.

Revilla, P., Abuin, M.C., Malvar, R.A., Soengas, P., Ordas, B., \& Ordas, A. (2005). Genetic variation between Spanish and American version of sweet corn inbred lines. Plant Breed, 124, 468-271.

Revilla, P., Rodriguez, V.M., Malvar, R.A., Butron, A., \& Ordas, A. (2006). Comparison among sweet corn heterotic patterns. J. Amer. Soc. Hort. Sci., 131, 388-392.

Rupp, J.V., Mangolin, C.A., Scapim, C.A., Machado, M.F. (2009). Genetic structure and diversity among sweet corn (sul-germplasm) progenies using SSR markers. Maydica, 54, 125-132.

Smith, J.S.C., \& Smith, O.S. (1989). The description and assessment of distances between inbred lines of maize: I. The use of morphological traits as descriptors. Maydica, 34, 141-150.

Srdić, J., Nikolić, A., Pajić, Z., Mladenović Drinić, S., \& Filipović, M. (2011). Genetic similarity of sweet corn inbred lines in correlation with heterosis. Maydica, 56, 251-256

Tracy, W.F. (1990). Potential of field corn germplasm for the improvement of sweet corn. Crop Sci., 30, 1041-1045.

Tracy, W.F. (2001). Sweet corn. In: A.R. Hallauer (ed.). Specialty Corns, second edition. CRC Pres LLC, 2000 N.W. Corporate Blvd., Boca Raton, Florida 33431, USA, 156-188.

Tracy, W.F., Talbert, L.E., \& Gerdes, J.T. (2000). Molecular variation in $\mathrm{F} 1$ performances among strains of sweet corn inbred P39. Corp Sci., 40, 1763-1768.

UPOV TG/2/6+Corr. (1999). Guidelines for the conduct of tests for distinctness, uniformity and stability. International Union for the Protection of New Varieties of Plants, Geneva.

UPOV TG/2/7 (2009). Guidelines for the conduct of tests for distinctness, uniformity and stability. International Union for the Protection of New Varieties of Plants, Geneva.

\section{Predviđanje heterozisa na osnovu fenotipske distance roditeljskih linija kukuruza šećerca}

\section{Vojka Babić · Jelena Srdić • Zorica Pajić · Nikola Grčić · Milomir Filipović}

Sažetak: Relativno uska genetička osnova, ograničeni resursi germplazme koja zadovoljava komercijalne standarde, loše definisane heterotične grupe kao i kratko vreme koje je na raspolaganju za procenu prinosa i kvaliteta su razlozi slabijeg unapređenja prinosa hibrida kukuruza šećerca u poređenju sa hibridima standardnog kvaliteta zrna. Stoga svaka dodatna informacija može da bude od velikog značaja. Na osnovu karakterizacije po UPOV deskriptoru urađena je klaster analiza 14 ZP linija kukuruza šećerca. Grupisanje je ukazalo da su se roditeljske linije 9 od 11 hibrida grupisale u različite podklastere. Dva hibrida, čije su se roditeljske linije grupisale u isti klaster su nosioci nekih specifičnih karakteristika kao što je ranostasnost (ZP 111su) i super-slatka germplazma (ZP 407su). Rezultati grupisanja dobijeni ovom procedurom mogu biti od velike pomoći pri izboru roditeljskih linija za buduća ukrštanja linija šećerca.

Ključne reči: fenotipovi, germplazma, heterosis, hibridi, inbred linije, kukuruz šećerac, UPOV deskriptor, Zea mays L. saccharata. 